\title{
福島原発事故後の復興に向けた今日までの進渉状況
}

\author{
小島周二, $*, a$ 井上浩 義 $b$
}

\section{Progress for the Revival after the Fukushima Nuclear Plant Accident to Date}

\author{
Shuji Kojima*,a and Hiroyoshi Inoue ${ }^{b}$ \\ ${ }^{a}$ Department of Radiation Biosciences, Faculty of Pharmaceutical Sciences, Tokyo University of Science (TUS); \\ 2641 Yamazaki, Noda, Chiba 278-8510, Japan: and ${ }^{b}$ Department of Chemistry, Keio University School \\ of Medicine; 4-1-1 Hiyoshi, Kohoku-ku, Yokohama 223-8521, Japan.
}

2011 年 3 月 11 日に起きた東日本大震災に伴う福 島第一原発事故以降，“放射線を正しく理解し，正 しく怖がりましょう”というフレーズを見聞きしな い日はなかった。原発事故発生に伴い，核反応によ り生成された放射性ヨード $\left({ }^{131} \mathrm{I}\right)$ やセシウム $\left({ }^{134} \mathrm{Cs}\right.$, $\left.{ }^{137} \mathrm{Cs}\right)$ が風に乗り，主として東北・関東地方に飛 散，その後の降雨により地上に落下，露地野菜や水 道水等に混入，日常生活がパニックに陥る事態にま でに至った。事故後，復興に向けて，污染地区の特 定, その後の除染等に国を挙げて今日まで対処し, 既に 2 年を経過したが，今日でも放射性セシウムに よる下水溝や野菜・魚介類の污染が多くの人々に恐 怖心を与えているのが現状である.

福島原発事故後の復興のためのこれまでの試みと 今後の課題等を各分野のスペシャリストに提供して 頂き，それらを受けて，医療を担う一員である薬剤 師/薬学研究者である私達に何ができるか? ま た，得られた成果をできるだけ早期に復興に生かし ていくための取り組みについて参加の皆様と議論で きる場としたいという思いから，本シンポジウムを
設定させて頂いた.

具体的には，5名のシンポジストに登壇頂き，1） 福島原発事故一残された健康リスクのアセスメント とコントロール (長崎大先導研 松田尚樹)，2）福 島原発事故後の陸域での放射性物質の環境動態（筑 波大 RI センター 古川 純)，3）東電福島原発事 故後の海洋での放射能污染の推移（気象研 青山道 夫),4）低線量放射線の生体影響（東京理大院薬学 研究科 小島周二)，及び5）わが国での今後の放 射線教育はごうあるべきか?（慶應大 井上浩義） の各演題で,「復興の現状」,「陸地の除染と植物へ の放射性セシウムの移行」, 「現在と今後の海洋と魚 への污染状況」,「人体の被ばく線量とその影響」,

及び「現地での放射線教育の現状」等を各専門家に 最新の状況を紹介して頂いた。 しかしながら, 講演 時間の関係でカバーできなかつた箇所も多々あった ようだが，幸いにも本誌編集事務局より今回のシン ポジウム内容に基づいた誌上シンポジウムの機会を 与えられたので, 各先生方にはその内容も含めて原 稿をお願いした。

\footnotetext{
$a$ 東京理科大学大学院薬学研究科 (干278-8510 千葉県野 田市山崎 2641), $b$ 慶應義塾大学医学部化学教室 (T223 -8521 横浜市港北区日吉 4-1-1)

*e-mail: kjma@rs.noda.tus.ac.jp

日本薬学会第 133 年会シンポジウム S30-301 序文
} 